\title{
CHEMICAL AND PHYSICAL FACTORS OF FIBERS ON ENZYME LEAKAGE AND MORPHOLOGICAL CHANGES OF GRANULOCYTES ADHERING TO FIBERS ${ }^{* 1}$
}

\author{
By Masaki Miyamoto ${ }^{* 2}$, Kenji Honda ${ }^{* 3}$ and Shigeru Sasakawa \\ (Department of Research, Central Blood Center. \\ Japanese Red Cross, 4 Hiroo, Shibuya-ku, Tokyo 150, Japan)
}

\begin{abstract}
We have evaluated the compatibility of various fibers as the leukocytes separators by the quantification of the amounts of enzymes which were leaked from adhering granulocytes to fibers. When granulocytes adhered to synthetic and natural fibers, changes in the shape of adhering cells and leakage of lysosomal enzymes were observed, depending on the chemical and physical structure of fibers. However, morphological changes and enzyme leakage were not always correlative. Physical factors such as the diameter and the shape of fibers were important. These changes increased as the diameter of fibers decreased. They could be suppressed by coating the surface of fiber with albumin.
\end{abstract}

\section{INTRODUCTION}

In most transfusion, patients need a specific component of blood instead of whole blood. Recently, the blood component therapy is widely used in transfusion. As the result, the establishment of a cell separation system for such purpose is desired at blood centers ${ }^{1}$.

The authors have been developing a cell separator of human leukocytes for the preparations of (1) granulocytes and leukocyte-poor erythrocytes for transfusion and of (2) purified lymphocytes for the production of interferon and transfer factor. A new system, using various synthetic fibers, is applied to the development of cell separation on the basis of the so-called adherence chromatography. This methodology has already been applied to filtration leukapheresis for granulocyte transfusion ${ }^{2)}$. It has been, however, pointed out $^{3)-7)}$ that this is inferior to the centrifugation method in regard to the functional damage of the collected cells, although there are many merits in this method, such as the high recovery and high purity of granulocytes. Therefore, the authors have been trying to overcome this defect by coat-

\footnotetext{
-1 Studies on Blood Cell Separation by Adherence Chromatography (part 2)

*2 To whom correspondence should be addressed.

*3 Present address: Solar Energy Research Institute Photoconversion Branch, Colo, U.S.A.
}

ing the fibers with albumin or gelatin. It was reported in the previous paper ${ }^{1)}$ that by using protein-coated fibers, improvements in the recovery and selectivity of separation of granulocytes from human leukocytes have been achieved. In this paper, the compatibility of various synthetic fibers as cell separator was evaluated by the quantification of the amounts of leaked lysosomal enzymes which were contained in azurophil or specific granules in cytoplasma. In addition, the relationship between enzyme leakages and the morphological changes of the adhering cells was discussed. Furthermore, natural fibers like silk and wool were also evaluated in comparison with the proteincoated fibers.

\section{MATERIALS AND METHODS}

Quantification of The Leakage of Lysosomal Enzymes. Various fibers were packed into a plastic syringe $(5 \mathrm{ml}$, Terumo Co., Ltd.) so as to keep a total surface area of approximately 120 $\mathrm{cm}^{2}$ This shows enough capacity for adhering of charged granulocytes to the fibers. Hank's medium ( $\mathrm{NaCl} 137 \mathrm{mM}$, KCl $5.4 \mathrm{mM}, \mathrm{Na}_{2} \mathrm{HPO}_{4} 0.4 \mathrm{mM}$, $\mathrm{KH}_{2} \mathrm{PO}_{4} 0.4 \mathrm{mM}, \mathrm{NaHCO}_{3} 0.4 \mathrm{mM}$, glucose 5.6 $\mathrm{mM}, \mathrm{CaCl}_{2} 1.0 \mathrm{mM}, \mathrm{MgCl}_{2} 1.0 \mathrm{mM}, \mathrm{pH} \mathrm{7.4) \text {was }}$ passed through the column in order to eliminate completely air bubbles in the column. Granulocytes, isolated from human blood of healthy donors by Ficoll-Conray method ${ }^{8}$; had the purity 
and the viability of granulocytes in the collected cells, $95 \%$ and $98 \%$, respectively. The granulocytes were suspended in Hank's medium at a cell density of $10^{7} \mathrm{cells} / \mathrm{ml}$. This cell suspension $(2 \mathrm{ml})$ was charged into the fiber column and then incubated $30 \mathrm{~min}$ at $37^{\circ} \mathrm{C}$. After the incubation, the amounts of lysosomal enzymes such as $\beta$-glucuronidase, lysozyme and lactic dehydrogenase (LDH) which had leaked out into the medium were quantified by the usual methods: $\beta$-glucuronidase was colorimetrically measured with $\mathrm{p}$-nitrophenyl- $\beta$-glucuronide as substrate ${ }^{9)}$, lysozyme was measured by the turbidimetric rate of lysis of Micrococcus lysodeikticus ${ }^{10}$ ), and LDH was measured by the rate of the decrease of NADH in the reduction of pyruvate ${ }^{11)}$. The enzyme leakage is indicated by percentage to the total enzyme activity leaked by $0.2 \%$ of Triton X-100.

Scanning Electron Micrographs (SEM) of Granulocytes Adhering to Fibers. After the removal of the medium from the fibers as described in the preceding section, the granulocytes adhering to the fibers were treated with $1.5 \mathrm{wt} \%$ glutaraldehyde in $0.1 \mathrm{M}$ cacodylate buffer containing $1 \%$ sucrose, $\mathrm{pH} 7.4$, at room temperature for $2 \mathrm{~h}$ and further fixed with $1 \mathrm{wt} \%$ osmium tetroxide in $0.1 \mathrm{M}$ phosphate buffer containing $4 \%$ sucrose, $\mathrm{pH} 7.4$, at $4^{\circ} \mathrm{C}$ for $1 \mathrm{~h}$. Then, the fixed cells were dried by gradual dehydration with a mixture of ethanol and water and additionally by criticalpoint drying for SEM observation ${ }^{12}$.

Fibers. Synthetic and natural fibers which were offered by Mitsubishi Rayon Co., Ltd., were washed with ethanol and sufficiently with distilled water before use. The diameters of the fibers used were measured by SEM. A surface area of fibers was calculated on the assumption that the fibers are cylindrical.

Coating of Fibers with Albumin. The fibers packed in a syringe were dipped in Hank's medium containing $1 \mathrm{wt} \%$ of human serum albumin (HSA) for $3 \mathrm{~h}$ at room temperature. Then, a large amount of Hank's medium was passed through the syringe. HSA was isolated from pooled plasma by the Cohn method ${ }^{(3)}$ at this center.

\section{RESULTS AND DISCUSSION}

The Enzyme Leakage and The Morphological Changes of Granulocytes Adhered to Fibers.
Granulocytes contain two kinds of granules in cytoplasma, azurophil and specific granules, in which many enzymes participating in bactericidal function are involved ${ }^{14)}$. In this work, $\beta$-glucuronidase and lysozyme, contained in azurophil and specific granules, respectively, were determined as a marker which indicates the functional damage of granulocytes ${ }^{1)}$, when they adhere to fibers. In addition, LDH was also measured as a marker of the damage of flasma membranes ${ }^{1)}$. The order of the degree of enzyme leakage for three kinds of lysosomal enzymes by adhering to the fibers was as follows: lysozyme $>\mathrm{LDH} \gg \beta$-glucuronidase. $\beta$-glucuronidase showed a very low leakage (max. $4 \%)$ at $37^{\circ} \mathrm{C}$ up to $120 \mathrm{~min}$. The phenomenon that the amount of lysosomal enzyme which is leaked from granulocytes adhered to fibers is different between azulophil and specific granules, has already been reported by Wright et al. ${ }^{15)}$ and it is also found in phagocytosis of microorganisms ${ }^{16)}$. When a granulocyte is allowed to adhere for 5 min to nylon 6 at $37^{\circ} \mathrm{C}$, pseudopod radiate from the spreading cell, as the cell flattens itself on the fiber surface. A cell after $30 \mathrm{~min}$ contact with the fibers fully spread out to a flattened hemisphere. In a granulocyte plated onto nylon 6 for $60 \mathrm{~min}$, the cytoplasma is already withdrawn from the periphery. However, although the morphological changes of granulocytes adhered to the fibers were thus marked, the enzyme leakage, especially the leakage of $\mathrm{LDH}$, was not so extensive.

Effect of Chemical Structure of Fibers. Fig. 1 and Fig. 2 show the degrees of leakage of lysozyme and $\mathrm{LDH}$, and the morphologies of granulocytes adhering to various fibers for $30 \mathrm{~min}$ at $37^{\circ} \mathrm{C}$. These observations show: (1) In the case of hydrophilic fibers such as cellulose (rayon and acetate) and vinylon, the enzyme leakage and the morphological change are relatively low. (2) In the case of polypropylene, the leakage of lysozyme and the morphological change are relatively low in spite of the highest leakage of LDH among the fibers used here. It is thus suggested that the degree of the leakage of lysosomal enzymes does not always correspond to the extent of the morphological change of adhering granulocytes. (3) In the case of nylon fibers, the degrees of both the leakage of lysozyme and morphological change 


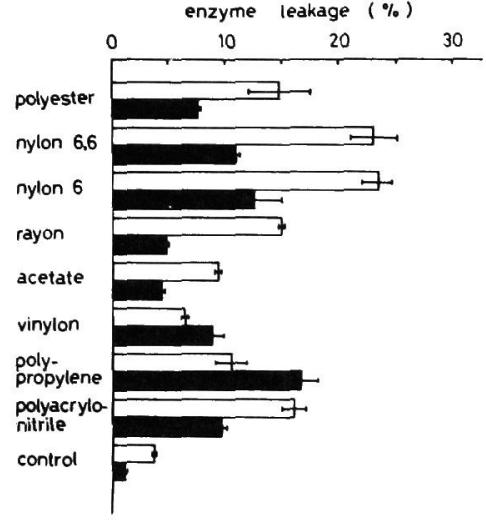

Fig. 1 Effects of chemical structure of fibers on enzyme leakage. The open and closed columns indicate the degrees of leakage of lysozyme and $\mathrm{LDH}$, respectively. Enzyme leakage was determined at $30 \mathrm{~min}$ after adhesion to fiber at $37^{\circ} \mathrm{C}$. The diameters of fibers $(\mu \mathrm{m})$ used here were polyester (12.4), nylon 6.6 (13.7), nylon 6 (13.7), rayon (11.9), actate (12.7), vinylon (12.9), polypropylene (15.3), and polyacrylonitrile (13.0).

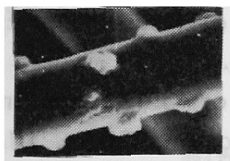

polyester

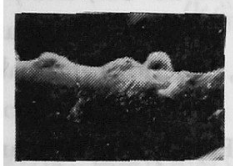

nylon 6.6

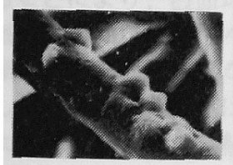

nylon 6

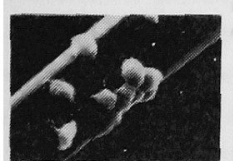

polypropylene

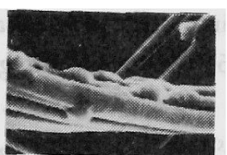

rayon

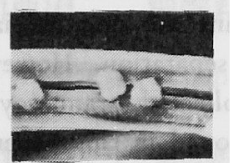

acetate

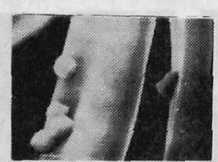

vinylon

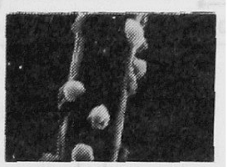

polyacrylonitrile

$$
20 \mathrm{\mu m}
$$

Fig. 2 Shapes of granulocytes adhering to various fibers $30 \mathrm{~min}$ after adhesion to fibers at $37^{\circ} \mathrm{C}$. The fibers used here were the same as in Fig. 1. are the highest. (4) In the case of acryl fibers, the degrees of the leakage of both LDH and lysozyme are relatively low, and in addition, the shape of adhering cells is mostly round.

In addition, more than $90 \%$ of granulocytes which were charged into the adherent column adhered to all fibers used in this experiment under the conditions described in the preceding section so that the difference in the degree of enzyme leakage was not due to the difference in the degree of adhesion of granulocytes to fibers. Moreover, there was no apparent loss of activities of the enzymes during the incubation period with fibers.

As described above, fibers having hydrophilic surface like cellulose or vinylon do not strongly damage granulocytes but have a low effect on the recovery and purity of granulocytes ${ }^{1)}$. There appears a contrary correlation in the separation of granulocytes by synthetic fibers between the capability of selective separation and functional integrity as indicated by lysosomal enzyme leakage. Moreover, these morphological changes indicate the degree of detachment of adhered cells as reported in our previous paper ${ }^{1)}$

Effect of Protein Coating of Fibers. Fig. 3 shows a comparison of enzyme leakage and the shape of adhering cells between HSA-coated fibers (nylon 6) and natural fibers (wool and silk). The HSA coating inhibited the leakage of lysozyme and LDH to a significant extent and also offered a suppression effect on morphological changes comparatively. Wool has a scale-like surface structure as shown in the SEM pictures of Fig. 3 , and there appeared a tendency that granulocytes preferentially adhered to the border areas between the scales by SEM observations of about 500 cells. There were observed both round and spread cells on the different surface areas. The degrees of the enzyme leakage of wool were almost the same as those of non-coated nylon 6. In the case of silk which has an elliptical cross section of fiber, pseudopod radiated from adhering granulocytes along the axis of the fibers, and the degree of enzyme leakage was significantly lower than those of wool and HSA-coated nylon 6. In addition, the degree of adhesion of granulocytes to silk or wool was as high as that to nylon 6 or to HSA-coated nylon 6. The differences in the morphology of adhering cells and enzyme leakage between wool 


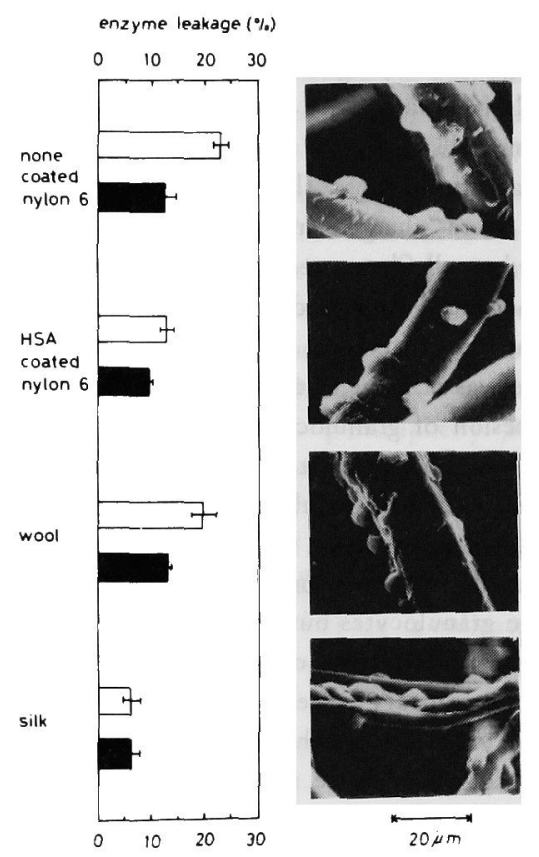

Fig. 3 Effects of protein coating of fibers on enzyme leakage and the morphological change of granulocytes $30 \mathrm{~min}$ after adhesion to fibers at $37^{\circ} \mathrm{C}$. The notations are the same as in Fig. 1.

and silk may be due to (1) the difference in such chemical factors as the structure of the proteins (keratin and fibroin) and/or due to (2) the difference in such physical factors as the shape of the fibers (diameter, shape of cross section, surface structure and others).
Effect of Diameter of Fibers. It was found in Fig. 4 that the degrees of enzyme leakage and the morphological changes increased as the diameter of acrylic fibers decreased. As shown in the electron micrograph of granulocytes adhered to the fiber of $3.8 \mu \mathrm{m}$ in diameter, it seems as if granulocytes phagocytosed the fibers. An observation similar to these results has been reported ${ }^{17)}$ : when granulocytes phagocytose, the rate of phagocytosis is greatly dependent on the size of the particles which are taken into the cytoplasma of granulocytes. It is thus shown that both morphological change and enzyme leakage are not only dependent on the chemical factors of fibers but also on their physical factors, such as the diameter and the shape of the fibers. Latter factors are very important in the cell interaction.

\section{CONCLUSION}

The following points for the evaluation of fibers as a leukocyte separator should be checked: (1) recovery (degrees of adhesion and detachment), (2) selectivity of separation of granulocytes and lymphocytes from leukocytes, (3) morphology of adhering cell, (4) leakage of lysosomal enzymes and (5) functional integrity.

In the markets, 1.5 or 3.0 denier nylon (Leukopak ${ }^{\circledR}$, Fenwal, Morton, Grove, III.) or polyester (Leukalum ${ }^{\circledR}$, Terumo Co., Ltd.) fiber columns are commercially available for granulocytes separation. However, functions and viability of collected granulocytes are not so good as mentioned in this paper. Finally, we recommend

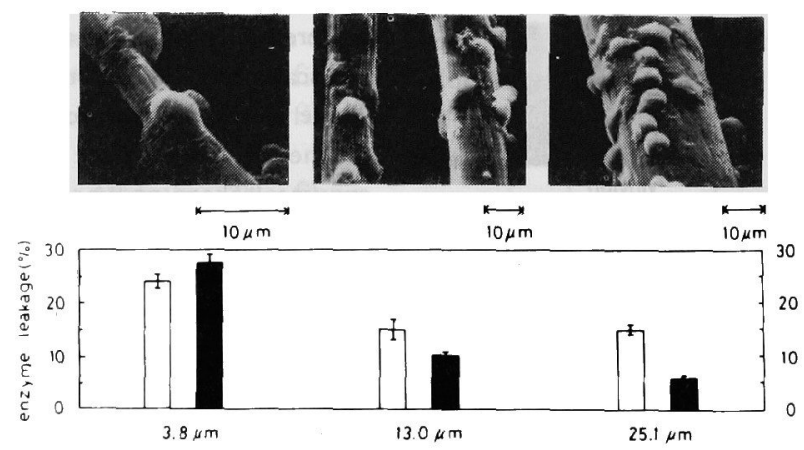

Fig. 4 Effects of diameter of acrylic fibers on enzyme leakage and morphological change of granulocytes $30 \mathrm{~min}$ after adhesion to fiber at $37^{\circ} \mathrm{C}$. The notations are the same as in Fig. 1. 
the HSA-coated fibers which have a diameter over $25 \mu \mathrm{m}$.

\section{ACKNOWLEDGEMENT}

We would like to thank Mr. Toshio Sakurai, Mitsubishi Rayon Co., Ltd. for supplying various fibers.

\section{ADDITION}

This study was reported at the Annual Meeting of the Society of Fiber Science and Technology, Japan, Tokyo, (Jun 18, 1980 and May 22, 1981).

\section{REFERENCES}

1) K. Honda, M. Miyamoto, and S. Sasakawa, Sen-i Gakkaishi, 36, 496 (1980)

2) I. Djerassi, J. S. Kim, C. Mitrakul, U. Suvansri, and W. Ciesielka, J. Med., 1, 358 (1970)

3) S. C. Finch, J. Jap. Soc. Blood, Transfusion, 24, $136(1974)$

4) D. G. Wright, J. C. Kauffman, M. J. Chusid, G. P. Herzig, and J. I. Gallin, Blood, 46, 901 (1975)

5) J. McCullough, B. J. Weiblen, A. R. Deinard, J. Boen, I. E. Fortuny, and P. G. Quie, Blood, $48,315(1976)$
6) C. Ts'ao, and E. A. Ruder, Transfusion, 16 , $336(1976)$

7) P. H. Wadw, E. M. Skrabut, L. Vinciguerra, and C. R. Valeri, Transfusion, 17, 136 (1977)

8) A. Böyum, Scand, J. Clin. Lab. Invest. (Suppl.), 97, 51 (1968)

9) J.H. Glaser, and W.S. Sly, "Methods in Enzymology", 50, Academic Press, New York, p. 451 (1978)

10) G. Litwach, Proc. Soc. Exp. Biol. Med., 89, 401 (1955)

11) F. Wroblewski, and J. S. Ladue, Proc. Soc. Exp. Biol. Med., 90, 210 (1955)

12) J. Boyles, and D. F. Bainton, J. Cell Biol, 82, 347 (1979)

13) E. J. Chon, L. E. Strong, W. L. Hughes, Jr, D. J. Mulford, J. N. Ashworth, M. Melin, and H. L. Taylor, J. Am. Chem. Soc., 72, 459 (1946)

14) D.F. Bainton, J.L. Ullyot, and M.G. Farquhar, J. Exp. Med, 134, 904 (1971)

15) D. G. Wright, J.C. Kauffman, G. K. Terpstra, R. G. Graw, A. B. Deosseroth, and J. I. Gallin, Blood, 52, $770(1978)$

16) D. F. Bainton, J. Cell Biol., 58, 249 (1973)

17) J. Roberts, and J.H. Quastel, Biochem. J., 89, $150(1963)$

顆粒球の粘着北態および酵素漏出に及ぼす緎維の物理・

化学的要因細胞粘着法に上る血球分離 (II)

日本赤十字社中央血夜センター・研究部宮本正樹，本田憲治，笹川滋

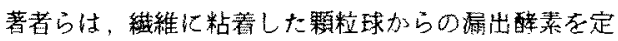

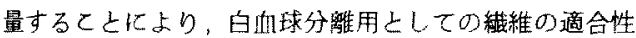

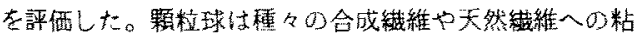
着化伴い，形態変化が起こり，細胞内加種々の醉素加 漏出した。これらの変化は，䄉維の化学構造や物理的形 状により異なり，また，粘着形態变化と醉素漏出量は，
必ずしる対应しなかった。䄉維の形状は細胞との相互作 用には，重要であり，䋳維の太さが，顆精球より小さい

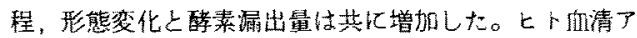
ルブミンをコートした瀻維は，細胞分稚を高く維持しな がら，練胞の機能保持にも効果が認められた。 